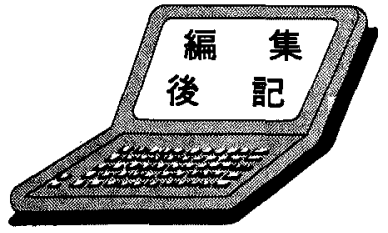

感謝いたします。

今月号は特集解説として, 岐帛大学の河瀬順洋先生に 「回転機の電磁界解析技術とその応用」と題する解説記事 を執筆していただきました。この記事では，回転機の電磁 界解析技術の動向, 具体的解析例を紹介していただきまし た。解析例も視覚的に示されているためわかりやすく，興 味深く読んでいただけたものと思います。学界情報では， 東京工業大学の竹本真紹氏にミレニアムを記念してローマ
で開催されましたIEEE IAS 2000 につまして，ローマ の雲囲気，IAS での論文発表状況，日本の産業応用部門 関係者の表彰などをレポートしていただきました。また， 技術開発レポートでは，東芝の千田有一氏に「セントリフ ュージロータの開発」と題しまして，宇宙空間という特殊 環境における人工重力環境発生装置を紹介していただきま した。高精度な重力環境を作るのは非常に大変なことがよ くわかりました。研究グループ紹介では，九州大学の谷口 倫一郎先生より画像処理技術の例として，人の動作を実時 間で画像のキャラクタに反映する興味ある研究を紹介して いただきました。

今後とも，読者の皆様の興味をそそる部門誌を製作して いきたいと思っていますのでよろしくお願いします。 エディ夕 奈良 秀隆 (明電舎)

\title{
3 月号特集「半導体電力変換技術と光の応用」予告
}

高速スイッチングデバイスの特性改善や新デバイスの出現, マイクロプロセッサなどのディジタル制御機器 の性能向上や高性能制御技術の研究開発が活発に繼続的に行われて, 半導体電力変換技術はますます発展し, その応用範囲は拡大しています。特に，近年の環境・エネルギー問題に対する関心の高まりから，電力応用の 大容量分野から電気自動車ドライブ応用・スイッチング電源応用などの小容量分野に至るまで, 半導体電力変 換技術は省エネルギーを達成するためのキーテクノロジーとなっています。

このような背景から, 電力用半導体デバイスの利用技術, 電力変換器の回路・制御・応用技術, EMI/ $\mathrm{EMC}$ ・高調波抑制などの半導体電力変換技術について, 特集論文を企画しました。この特集に対しては 9 件 の論文が投稿され，そのうちの査読が終了した論文を揭載することになります。また，特集解説としては電力 供給システムに適用される電力変換機器を念頭に置いて, 直流送電などへ応用する高圧電力変換技術と, 分散 電源などへ応用する低圧電力変換技術という視点から紹介するように企画しました。ご期待ください。

\section{お詫びと訂正}

電気学会産業応用部門誌 121 巻 1 号（平成 13 年 1 月号）の表紙に下記のような誤りがありました。お詫びして言正いたします。

\begin{tabular}{|c|c|}
\hline 誤 & 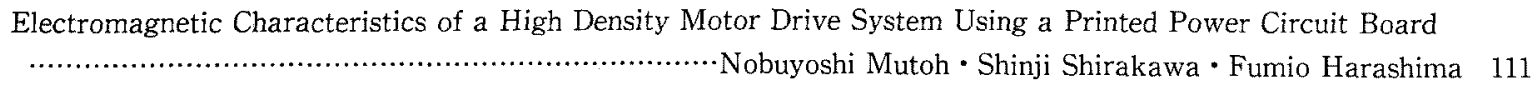 \\
\hline 正 & $\begin{array}{r}\text { Electromagnetic Characteristics of a High Density Motor Drive System Using a Printed Power Circuit Board } \\
\text { Sadao Hokari } \cdot \text { Fumio Harashima } 111\end{array}$ \\
\hline
\end{tabular}

